\title{
The English Experience Serves as a Pronunciation Guide Allowing Students by Analogy to Learn Spelling in Taiwan Aboriginal Languages: An Example of the Amis Ethnicity
}

\author{
Tung-Chiou Huang*, Akiyo Pahalaan \\ Institute \& Department of Foreign Languages \& Cultures, Fo Guang University, Taiwan
}

Copyright $(2016$ by authors, all rights reserved. Authors agree that this article remains permanently open access under the terms of the Creative Commons Attribution License 4.0 International License

\begin{abstract}
Orthography is a set of conventions for representing language in written form; written forms are made up of graphic words, and such words, taking English for example, are composed by individual graphs or letters that represent sounds. Thus, writing systems are conventional visible marks for human communication (Gelb,1963: 12; Burnaby, 1997: 59; DeLancey, 1998). Written communication, furthermore, allows a culture to communicate in written form with its ancestors and with its progeny by crossing physical and time boundaries. All aboriginal languages spoken in Taiwan were in the past orally transmitted. As Fishman (1980: 169) writes, "Unless they are entirely withdrawn from the modern world, minority ethno-linguistic groups need to be literate in their mother tongue (as well as in some language of wider communication)." However, the language becomes vastly easier to learn and literacy is improved when the writing system is consistent. In Taiwan since 2001, English has been taught in our educational system from the fifth grade of the primary school onward. Students, therefore, know the alphabet and learn both the shapes of its 26 letters, the letter names, and the phonemic correspondence to these graphs, and it would be much easier to learn a system of phonetics for a pre-literate or semi-literate people group that uses letters found in the English alphabet, for the English experience serves as a pronunciation guide allowing students by analogy to learn spelling in their aboriginal languages. My intention in this paper through action research is to share what has been done for over thirty years to capitalize upon the fact that the students in Taiwan are already familiar with alphabetic writing because of their prior study of English. They would, therefore, be well-placed to transfer the regular sound-letter association which they have learned in English classes to the representation of the sounds of the various aboriginal languages of Taiwan. The great benefit of it is to make acknowledgement of the theme of translingualism, a process of empowerment. This empowerment of us in our
\end{abstract}

daily life might produce an environment that fosters maturity and responsibility for our own circumstances. In a word, it would be easier to learn a system of phonetics that uses letters found in the English alphabet that serve as a pronunciation guide while making analogy in learning aboriginal languages.

Keywords Orthography, Aboriginal Languages, Analogy, Transfer, Translingualism

\section{Introduction}

Orthography is a set of conventions for representing language in written form; written forms are made up of words, and words, taking English for example, have letters that represent sounds (Huang, T-C. 2002, 2014). Bringing out students' awareness of letter-sound correspondences is an important aim for the courses of phonetics and the present book (Diaz-Rico, L. 2004).

The languages which will form the basis for the language awareness program, which we would outline in this study, are largely unwritten. The issue of how these languages should be represented in writing is thus a matter of considerable practical and theoretical importance. In this book, therefore, we first consider the issues involved in devising a writing system for a language; then several romanized alphabetic schemes in use in Taiwan will be introduced based both on a review of the literature and personal learning and teaching experience of twenty years. We also explain the principles of the system adopted for the current study: how the scheme is to be used and how we hope to apply these principles in order to help students transfer their English language skills to learning aboriginal languages (Huang, T-C. 1994, 2002, 2014). 


\section{Literature Review}

The endangered languages exist predominantly as oral tradition without literacy have a profound impact on their survival, and the nature of efforts for reversal required to strengthen them (RCAP, 1996: Vol. 3). In general, languages with literary traditions survive longer than those with only oral traditions, and literacy is one of the keys to Hebrew revival because it makes Hebrew never die completely. Fishman's (1980: 169) writes, "Unless they are entirely withdrawn from the modern world, minority ethno-linguistic groups need to be literate in their mother tongue (as well as in some language of wider communication)".

It is the main reason most language efforts almost instinctively place a high premium on literacy. Paulston (1992: 61) notes, "Literacy is a way to spread Swahili. Swahili newspapers were founded, and village headmen made reports in Swahili." In Taiwan, in order for adult literacy to take place and the generations being able to be united through community language literacy, there need to be easy-reading literacy materials and dictionaries. The present study is exploring the question of "What are the issues that arise when the English orthography is used in the teaching of community languages?" The following is what I have done for the literature.

\subsection{Writing System}

Writing systems are conventional visible marks for human communication (Gelb,1963: 12; Burnaby, 1997: 59; DeLancey, 1998). Written communication allows a culture to communicate with its ancestors and with its progeny and can cross physical and time boundaries. It is important at the outset to make the distinction between writing systems, scripts, and orthography. According to Coulmas (1989: 38-39), a 'writing system' makes a selection of the linguistic units to be graphically represented' (e.g. syllable writing or phonetic writing); a 'script' makes a specific selection of the possibilities of a given system in accordance with the structural conditions of a given language (e.g. Chinese script or Arabic script); and an 'orthography' makes a specific selection of the possibilities of a script for writing a particular language in a uniform and standardized way' (e.g. Standard German / Swiss German orthography).

Most academic discussions on writing systems, however, focus on the relationship between spoken language and sets of written symbols. There are no pure systems of writing, just as there are no pure races in anthropology and no pure languages in linguistics (Gelb, 1963: 199). There are, however, four main categories of writing system (Burnaby, 1997: 60):

1. Word-concept characters, commonly called ideographs (more properly called logographs), as in Chinese. Each character used in writing represents an idea or concept, more strictly a morpheme, i.e. a meaningful linguistic form, rather than a sound.

2. Syllable-sound characters, often called syllabaries, as in Japanese, many Indian languages or Cherokee. Each character represents the sound of a syllable, which may consist of a single phoneme or a group of phonemes.

3. Letter-sound characters, as in all alphabetic languages, such as English and Russian (Cyrillic). Each letter represents the sound of one, or sometimes more phonemes. Alternatively a combination of letters can represent one phoneme.

4. Consonantal writing, used to represent languages like Hebrew and Arabic, in which the characters represent consonants.

Table 1 below represents the main features of these four categories of writing systems (Taylor \& Olson, 1995: 5; Deniel \& Wouldiam, 1996).

Table 1. Main features of different writing systems

\begin{tabular}{|c|c|c|c|}
\hline Writing system & Languages & Advantages & Disadvantages \\
\hline Word-concept characters & $\begin{array}{c}\text { 1. Chinese } \\
\text { 2. Kanji of Japanese }\end{array}$ & $\begin{array}{c}\text { Characters represent words, and each symbol } \\
\text { represents one idea. }\end{array}$ & $\begin{array}{c}\text { Hundreds of symbols and radicals must be } \\
\text { recognised if one wants to be literate. }\end{array}$ \\
\hline Syllable-sound characters & $\begin{array}{c}\text { 1. Japanese } \\
\text { 2. Cherokee }\end{array}$ & Characters represent syllables. & $\begin{array}{c}\text { It is not useful in languages with complex } \\
\text { syllable patterns. }\end{array}$ \\
\hline Letter-sound characters & $\begin{array}{c}\text { 1. English } \\
\text { 2. Russian }\end{array}$ & Ease of learning. & $\begin{array}{c}\text { Spelling is notoriously difficult due to dialect } \\
\text { or historical changes, or borrowed words. }\end{array}$ \\
\hline Consonant-sound characters & $\begin{array}{c}\text { 1. Hebrew } \\
\text { 2. Arabic }\end{array}$ & $\begin{array}{c}\text { Better suited to languages with highly } \\
\text { predictable vowels, e.g. Arabic. }\end{array}$ \\
\hline
\end{tabular}


Over the past several years, there has been a growing consensus that the orthography of unwritten languages should be based on the alphabetic principle, possibly as a result of the importance of English as a global language. As DeLancey (1998) points out:

People in contemporary Native communities sometimes prefer an English-based orthography on the grounds that it is easier to learn for people who have already mastered literacy in the dominant language.

\subsection{Considerations in devising a Writing System}

There are three important considerations in devising a writing system for a language: economy, consistency and convenience (Fishman, 1968; Tsao, 1999a: 360).

Gelb (1963: 63) proposed economy as an important principle in the development of writing systems. The aim should be to represent the language by means of the smallest number of signs, resulting in simplicity, unequivocalness and faithfulness (Coulmas, 1996: 138). In alphabetic writing, an efficient system would allocate a symbol to each phoneme and there is no need to provide additional symbols if there is no phonemic contrast.

Consistency allows readers to pronounce words from their spelling, and writers to spell them from their sound. The letters should correspond predictably to speech sounds; all spellings are consistently pronounced. In other words, one symbol stands for one sound and there are no other symbols that stand for the same sound. Consistency permits learners to see what they say.

Convenience includes a number of notions. First of all, a set of letters is viewed as convenient if it can be easily learned, for they are easily associated with the sounds they represent. Secondly, the writing system is easily processed both mechanically and electronically without the use of large numbers of diacritics and additional letters. Most important, the same symbols can be generally used, allowing for slight modifications, in a number of closely associated languages.

An optimal writing system is easily acquired by beginning readers and writers and by those from different educational backgrounds (Rogers, 1995: 31; Taylor \& Olson, 1995: 7). It follows from what has been said that only when a set of letters is scientifically and socially acceptable can it be successful (Berry, 1972: 737; Her, Der-Hua 1994: 142).

In our present study these days, we have been guided by the five criteria for an optimal writing system proposed by Coulmas (1989: 226): 1) maximum motivation for the learner; 2) maximum representation of speech; 3 ) maximum ease of learning; 4) maximum transfer; 5) maximum ease of reproduction (Huang, T-C. 2002).

\subsection{The Writing Systems of Taiwan}

We have already discussed the principles which underline the logographic writing system of Chinese: one sign primarily represents one syllable and the meaning of a word or morpheme, and secondarily its sound. In alphabetic languages, one letter represents one phoneme, the basic principle of which is one symbol - one sound (Taylor \& Olson, 1995: 3; Hoosain, 1995: 131). In addition to the logographic writing system used for Chinese, there are, however, several Romanized systems.

For centuries, there was no standard orthography for languages other than Mandarin spoken in the Taiwan area. In addition to the traditional logographic writing, several Romanized scripts have been developed to represent both Chinese and the aboriginal languages. As Tsao (1999a: 359) points out,

A heated debate has been raging in Taiwan for the past three years having to do with the National Phonetic Symbols (NPS). .... and it is difficult to see what the outcome of this policy deliberation would be.

Students in Taiwan learn the National Phonetic Symbol 1 (NPS1) (henceforth N1), which uses components of traditional Chinese characters in the first 10 weeks of elementary school as an aid to learning Mandarin. In 1986, the Ministry of Education introduced the National Phonetic Symbol 2 (NPS2) (henceforth N2), which employs Romanized letters. However, this system is not taught compulsorily, and therefore is not widely used. Another set of alphabetic symbols promoted by Mainland China since 1956, officially known as Chinese Phonetic Scheme/ Hanyu Pinyin system (henceforth C), has been used for more forty years without any reported undesirable effects. The Tongyong Pinyin system (henceforth $T$ ) has recently been developed locally in Taiwan (Zhou, Her 1990: 2016; Chen, Li-Hung 1993; Tsao, 1999a: 361). Table 2 below compares the ways in which these four systems represent the sounds of Mandarin.

In reality, $\mathrm{N} 2, \mathrm{C}$, and $\mathrm{T}$ correspond closely to one another. C's main potential drawback is its use of letters $j, q$ and $x$ to represent Mandarin sounds that lack a handy equivalent in the Latin alphabet. From my point of view, the crux of the controversy is the use of the symbol ' $q$ ' to represent the sound of an aspirated palatal affricate [q], and symbol ' $x$ ' to represent the corresponding palatal fricative $[\mathrm{x}]$ when these letters correspond to completely different sounds in the Roman alphabet, sounds, which do not exist in English. It can be argued that the main issue here is not which system we should adopt or whether we can reasonably expect the young to learn all of them, but how we can make them easier for students to learn (Huang, T-C. 2002, 2014).

The choice of system cannot be thought of in simplistic terms, such as which is technically the most efficient. Broader political considerations, such as the global tendency towards alphabetic writing and the fact that large numbers of Mainland Chinese already use a system of Romanized writing, need also to be taken into consideration. It is clearly important that the advantages and disadvantages of the various systems become the focus for wide debate within Taiwan. 
Table 2. A comparison of various system used to represent Mandarin

\begin{tabular}{|l|l|l|l|}
\hline N1 & N2 & C & T \\
\hline
\end{tabular}

$\mathbf{N} 1=$ Chinese $; \mathbf{N} 2=$ Gwoyeu Romatzyh $; \mathbf{C}=$ Hanyu Pinyin $; \mathbf{T}=$ Tongyoung Pinyin

Initials

\begin{tabular}{|c|c|c|c|c|c|c|c|c|c|c|c|c|c|c|c|c|c|c|c|c|}
\hline \multirow{3}{*}{ Labials } & \multicolumn{4}{|c|}{$\begin{array}{l}\text { Unaspirated } \\
\text { stops }\end{array}$} & \multicolumn{4}{|c|}{ Aspirated stops } & \multicolumn{4}{|c|}{ Nasals } & \multicolumn{4}{|c|}{ Fricatives } & \multicolumn{4}{|c|}{ Voiced continuants } \\
\hline & N1 & $\mathrm{N} 2$ & $\mathrm{C}$ & $\mathrm{T}$ & N1 & $\mathrm{N} 2$ & $\mathrm{C}$ & $\mathrm{T}$ & N1 & $\mathrm{N} 2$ & $\mathrm{C}$ & $\mathrm{T}$ & $\mathrm{N} 1$ & $\mathrm{~N} 2$ & $\mathrm{C}$ & $\mathrm{T}$ & N1 & $\mathrm{N} 2$ & $\mathrm{C}$ & $\mathrm{T}$ \\
\hline & 々 & $\mathrm{b}$ & $\mathrm{b}$ & $\mathrm{b}$ & 文 & $\mathrm{p}$ & $\mathrm{p}$ & $\mathrm{p}$ & $\Pi$ & $\mathrm{m}$ & $\mathrm{m}$ & $\mathrm{m}$ & $ᄃ$ & $\mathrm{f}$ & $\mathrm{f}$ & $\mathrm{f}$ & & & & \\
\hline Alveolars & 分 & $\mathrm{d}$ & $\mathrm{d}$ & $\mathrm{d}$ & 去 & $\mathrm{t}$ & $\mathrm{t}$ & $\mathrm{t}$ & 3 & $\mathrm{n}$ & $\mathrm{n}$ & $\mathrm{n}$ & & & & & 力 & 1 & 1 & 1 \\
\hline Gutternals & $《$ & $\mathrm{~g}$ & $\mathrm{~g}$ & $\mathrm{~g}$ & 万 & $\mathrm{k}$ & $\mathrm{k}$ & $\mathrm{k}$ & & & & & $\Gamma$ & $\mathrm{h}$ & $\mathrm{h}$ & $\mathrm{h}$ & & & & \\
\hline Palatals & 4 & $\mathrm{j}(\mathrm{i})$ & $\mathrm{j}$ & $\mathrm{ji}$ & $<$ & chi & $q$ & $\mathrm{ci}$ & & & & & $T$ & shi & $\mathrm{x}$ & $\mathrm{si}$ & & & & \\
\hline Retroflexes & 出 & $\mathrm{j}$ & $\mathrm{zh}$ & jh & 彳 & $\mathrm{ch}$ & $\mathrm{ch}$ & $\mathrm{ch}$ & & & & & 户 & $\mathrm{sh}$ & sh & sh & 日 & $\mathrm{r}$ & $\mathrm{r}$ & $\mathrm{r}$ \\
\hline Alveolar sibilants & p & $\mathrm{tz}$ & $z$ & $\mathrm{z}$ & 方 & ts & $\mathrm{c}$ & $\mathrm{c}$ & & & & & $\angle$ & $\mathrm{s}$ & $\mathrm{s}$ & $\mathrm{s}$ & & & & \\
\hline
\end{tabular}

Finals/Rimes

\begin{tabular}{|c|c|c|c|c|c|c|c|c|c|c|c|c|c|c|c|c|}
\hline \multicolumn{17}{|l|}{ Finals/Rimes } \\
\hline Types & N1 & $\mathrm{N} 2$ & $\mathrm{C}$ & $\mathrm{T}$ & N1 & $\mathrm{N} 2$ & $\mathrm{C}$ & $\mathrm{T}$ & N1 & $\mathrm{N} 2$ & $\mathrm{C}$ & $\mathrm{T}$ & N1 & $\mathrm{N} 2$ & $\mathrm{C}$ & $\mathrm{T}$ \\
\hline \multirow[t]{2}{*}{ Single rimes } & 1 & $\begin{array}{l}-\mathrm{i} / \\
\mathrm{yi}\end{array}$ & $\begin{array}{l}-\mathrm{i} / \\
\mathrm{yi}\end{array}$ & $\begin{array}{l}-\mathrm{i} / \\
\mathrm{yi}\end{array}$ & $x$ & $\begin{array}{l}-\mathrm{u} / \\
\mathrm{wu}\end{array}$ & $-\mathrm{u} / \mathrm{wu}$ & $\begin{array}{l}-\mathrm{u} / \\
\mathrm{wu}\end{array}$ & 山 & $\begin{array}{l}-\mathrm{iu} / \\
\mathrm{yu}\end{array}$ & $\begin{array}{l}-\ddot{\mathrm{u}} / \\
\mathrm{yu}\end{array}$ & yu & & & & \\
\hline & Y & $\mathrm{a}$ & $\mathrm{a}$ & $\mathrm{a}$ & ट & o & o & o & さ & $\mathrm{e}$ & $\mathrm{e}$ & $\mathrm{e}$ & せ & $\mathrm{e} / \ddot{\mathrm{e}}$ & $\ddot{\mathrm{e}}$ & $\mathrm{e}$ \\
\hline \multirow[t]{3}{*}{$\begin{array}{c}\text { Duplex } \\
\text { rimes }\end{array}$} & 牙 & ai & ai & ai & 乙 & ei & ei & ei & 幺 & $\mathrm{au}$ & ao & ao & ヌ & ou & ou & ou \\
\hline & 马 & an & an & an & 4 & en & en & en & 九 & ang & ang & ang & $\angle$ & eng & eng & eng \\
\hline & 儿 & er & er & er & & & & & & & & & & & & \\
\hline \multirow[t]{3}{*}{$\begin{array}{c}\text { Combined rimes } \\
1\end{array}$} & $\begin{array}{l} \\
Y\end{array}$ & $\begin{array}{l}\text {-ia/ } \\
\text { ya }\end{array}$ & $\begin{array}{l}-\mathrm{ia} / \\
\text { ya }\end{array}$ & $\begin{array}{c}-\mathrm{ia} / \\
\text { ya }\end{array}$ & $\begin{array}{l} \\
\text { U }\end{array}$ & $\begin{array}{l}\text {-ie/ } \\
\text { ye }\end{array}$ & $\begin{array}{l}\text {-ie/ } \\
\text { ye }\end{array}$ & $\begin{array}{l}\text {-ie/ } \\
\text { ye }\end{array}$ & $\frac{1}{\text { 牙 }}$ & yai & yai & yai & $\begin{array}{l}1 \\
\text { 幺 }\end{array}$ & $\begin{array}{l}\text {-iau/ } \\
\text { yao }\end{array}$ & $\begin{array}{l}\text { iao/ } \\
\text { yao }\end{array}$ & $\begin{array}{l}\text { iao/ } \\
\text { yao }\end{array}$ \\
\hline & $\begin{array}{l}1 \\
\text { 又 }\end{array}$ & $\begin{array}{l}\text {-iou/ } \\
\text { you }\end{array}$ & $\begin{array}{l}-\mathrm{iu} / \\
\text { you }\end{array}$ & $\begin{array}{l}-\mathrm{iu} / \\
\text { you }\end{array}$ & $\begin{array}{l}1 \\
\text { 马 }\end{array}$ & $\begin{array}{l}- \text { ian/ } \\
\text { yan }\end{array}$ & $\begin{array}{l}\text {-ian/ } \\
\text { yan }\end{array}$ & $\begin{array}{l}\text {-ian/ } \\
\text { yan }\end{array}$ & $\begin{array}{l}1 \\
4\end{array}$ & $\begin{array}{l}\text {-in/ } \\
\text { yin }\end{array}$ & $\begin{array}{l}- \text { in/ } \\
\text { yin }\end{array}$ & $\begin{array}{l}\text {-in/ } \\
\text { yin }\end{array}$ & $\begin{array}{l}1 \\
\text { 九 }\end{array}$ & $\begin{array}{l}\text {-iang/ } \\
\text { yang }\end{array}$ & $\begin{array}{l}\text {-iang/ } \\
\text { yang }\end{array}$ & $\begin{array}{l}\text {-iang/ } \\
\text { yang }\end{array}$ \\
\hline & $\begin{array}{l}1 \\
L\end{array}$ & $\begin{array}{l}\text {-ing/ } \\
\text { ying }\end{array}$ & $\begin{array}{l}\text {-ing/ } \\
\text { ying }\end{array}$ & $\begin{array}{l}\text {-ing/ } \\
\text { ying }\end{array}$ & & & & & & & & & & & & \\
\hline \multirow[t]{2}{*}{$\begin{array}{c}\text { Combined rimes } \\
\times \\
\end{array}$} & $\begin{array}{l}X \\
Y\end{array}$ & $\begin{array}{c}\text {-ua/ } \\
\text { wa }\end{array}$ & $\begin{array}{c}\text {-ua/ } \\
\text { wa }\end{array}$ & $\begin{array}{l}\text {-ua/ } \\
\text { wa }\end{array}$ & $\begin{array}{l}x \\
\text { ट }\end{array}$ & $\begin{array}{l}\text {-uo/ } \\
\text { wo } \\
\end{array}$ & $\begin{array}{c}\text {-uo/ } \\
\text { wo } \\
\end{array}$ & $\begin{array}{l}\text {-uo/ } \\
\text { wo } \\
\end{array}$ & $\begin{array}{l}x \\
\text { 万 }\end{array}$ & $\begin{array}{c}\text {-uai/ } \\
\text { wai } \\
\end{array}$ & $\begin{array}{c}\text {-uai/ } \\
\text { wai } \\
\end{array}$ & $\begin{array}{c}\text {-uai/ } \\
\text { wai }\end{array}$ & $\begin{array}{l}x \\
2\end{array}$ & $\begin{array}{l}\text {-uei/ } \\
\text { wei }\end{array}$ & $\begin{array}{c}\text {-uei/ } \\
\text { wei }\end{array}$ & $\begin{array}{c}\text {-uei/ } \\
\text { wei } \\
\end{array}$ \\
\hline & $\begin{array}{l}\times \\
\text { 马 }\end{array}$ & $\begin{array}{l}\text {-uan/ } \\
\text { wan }\end{array}$ & $\begin{array}{l}\text {-uan/ } \\
\text { wan }\end{array}$ & $\begin{array}{l}\text {-uan/ } \\
\text { wan }\end{array}$ & $\begin{array}{l}x \\
4\end{array}$ & $\begin{array}{l}\text {-uen/ } \\
\text { wen }\end{array}$ & $\begin{array}{l}\text {-un/ } \\
\text { wen }\end{array}$ & $\begin{array}{l}\text {-un/ } \\
\text { wen }\end{array}$ & $\begin{array}{l}x \\
\text { 九 }\end{array}$ & $\begin{array}{c}\text {-uang/ } \\
\text { wang }\end{array}$ & $\begin{array}{l}\text {-uang/ } \\
\text { wang }\end{array}$ & $\begin{array}{l}\text {-uang/ } \\
\text { wang }\end{array}$ & $\begin{array}{l}x \\
L\end{array}$ & $\begin{array}{l}\text {-ung/ } \\
\text { weng }\end{array}$ & $\begin{array}{l}\text {-ong/ } \\
\text { weng }\end{array}$ & $\begin{array}{l}\text {-ong/ } \\
\text { weng }\end{array}$ \\
\hline $\begin{array}{c}\text { Combined rimes } \\
\sqcup\end{array}$ & $\begin{array}{l}\text { 山 } \\
\text { 世 }\end{array}$ & $\begin{array}{l}\text {-iue/ } \\
\text { yue }\end{array}$ & $\begin{array}{l}\text {-ue/ } \\
\text { yue }\end{array}$ & $\begin{array}{l}\text {-ue/ } \\
\text { yue }\end{array}$ & $\begin{array}{l}\text { ㄴ } \\
\text { 马 }\end{array}$ & $\begin{array}{l}\text {-iuan/ } \\
\text { yuan }\end{array}$ & $\begin{array}{l}\text {-uan/ } \\
\text { yuan }\end{array}$ & yuan & $\begin{array}{l}4 \\
4\end{array}$ & $\begin{array}{l}\text {-iun/ } \\
\text { yun }\end{array}$ & $\begin{array}{l}\text {-un/ } \\
\text { yun }\end{array}$ & yun & $\begin{array}{l}\text { L } \\
\angle\end{array}$ & $\begin{array}{l}\text {-iung/ } \\
\text { yung }\end{array}$ & $\begin{array}{l}\text {-iong/ } \\
\text { yong }\end{array}$ & yong \\
\hline
\end{tabular}

\subsection{English Phonology}

All the students in senior high school have already learned English for three years at least, for English is taught in our educational system from the start of junior high school at the age of twelve. The students therefore know the alphabet and learn both the shapes of 26 letters and the letter names (see Appendix A) and the phonemic representation of letter name. From the chart, students enhance their understanding about phonemic representation of letter name, and know they have already learned the following vowels: /e/, /i/, / / /, /aI/, /o/, /u/, /a/, /I/, / /, and consonants: /b/; /s/; /d/; /f/; /dz/; / t $/ / ; / \mathrm{k} / ; / 1 /$; $/ \mathrm{m} / ; / \mathrm{n} / ; / \mathrm{p} / ; / \mathrm{r} / ; / \mathrm{t} / ; / \mathrm{j} / ; / \mathrm{v} / ; / \mathrm{w} / ; / \mathrm{z} /$.

According to the K.K Phonetic System by John Kenyon and Thomas A. Knott, the most widely used system in Taiwan, there are, 3 diphthongs, 14 monophthongs, and 24 consonants (See Table 3). English spelling is notoriously difficult for native and non-native speakers (Craig \& Alexander, 2001). For non-native speakers in particular, it is not only handled erratically by most people, but is also mispronounced because English orthography often does not represent unambiguously how words are pronounced. In other words, knowing how a word is pronounced does not guarantee one a great chance to be able to spell it, and knowing how a word is spelled only gives a clue as to how to pronounce it. Furthermore, there are some letters which do not represent any segments in a particular word, (e.g. through and sign); the same sound can be represented with different letters in different words, (e.g. rude, two and soup); the same letter can represent different segments in different words, (e.g. not and bone); a single letter can represent more than one sound, (e.g. exile and saxophone).

Although there is no exact correspondence between graphemes and phonemes, there are nonetheless many undeniable regularities in English orthography, particularly at the morphemic level (Barreiro, 1999). Students are, therefore, taught letter-sound correspondences on the basis of phonetically regular consonant vowel combinations (see Appendix B: The alliteration and rhyme of the letter-sound correspondences). 
Table 3. 3 diphthongs, 14 monophthongs, and 24 consonants

\begin{tabular}{|c|c|c|c|}
\hline 3 diphthongs & \multicolumn{3}{|c|}{ / aI /; / aU/; /D I/. } \\
\hline 17 vowels & Front & Middle & Back \\
\hline High & $\begin{array}{l}/ \mathrm{i} / \\
/ \mathrm{I} /\end{array}$ & $\begin{array}{l}|34| \\
|3|\end{array}$ & $\begin{array}{l}/ \mathrm{u} / \\
/ \mathrm{U} /\end{array}$ \\
\hline Middle & $\begin{array}{l}\mathrm{e} / \\
/ \varepsilon / \\
\end{array}$ & $\begin{array}{l}/ a / \\
\mid \wedge /\end{array}$ & $\begin{array}{l}/ \mathrm{o} / \\
/ \mathrm{J} /\end{array}$ \\
\hline Low & /æ/ & & /a/ \\
\hline
\end{tabular}

\begin{tabular}{|c|c|c|c|c|c|c|c|c|}
\hline 24 consonant & bilabial & Labio-dental & dental & alveolar & Palato-alveloar & palatal & velar & glottal \\
\hline plosive & $/ \mathrm{p} / ; / \mathrm{b} /$ & & & $/ \mathrm{t} / / \mathrm{d} /$ & & & $/ \mathrm{k} / ; / \mathrm{g} /$ & \\
\hline nasal & $/ \mathrm{m} /$ & & & $/ \mathrm{n} /$ & & & $/ \mathrm{g} /$ & \\
\hline trill & & & & $/ \mathrm{r} /$ & & & \\
\hline fricative & & $/ \mathrm{f} / ; / \mathrm{v} /$ & $/ \theta / ; / \mathrm{d} /$ & $/ \mathrm{s} / ; / \mathrm{z} /$ & $/ \mathrm{J} / ; / 3 /$ & & $/ \mathrm{j} /$ & \\
\hline $\begin{array}{c}\text { approximant } \\
\text { Lateral } \\
\text { approximant }\end{array}$ & $/ \mathrm{w} /$ & & & & & & & \\
\hline \begin{tabular}{c} 
affricate \\
\hline
\end{tabular} & & & & $/ \mathrm{l} /$ & & & & \\
\hline
\end{tabular}

Thus, despite the many irregularities of English orthography, students are introduced to regular sound-letter correspondences as part of English lessons. This knowledge is further reinforced by the fact that English is an international language and plays a particularly important role in electronic communication and the Internet. Many students actually recognize letters in the English alphabet even before they enter junior high school. Furthermore, from 2001 English was introduced in the fifth grade in primary school (Tsao, 1999a:367; 2001). Given these considerations of economy and convenience, there are compelling reasons for using a Romanized Writing System based on English in representing the other languages of Taiwan which would serve as the focus for the present study (Edmondson \& Huang, 2004, 2005 ; Huang, T-C. 2002, 2014). All my students in my many different courses might realize that Translingualism lets the students feel that there is a real neighbourhood of speaking different languages at a time.

Kuwara benekis, merehuw, rawin, meceswey, Lokah simu? Peqasun balay niyux ta meseli seqani. Lalu mu ga Yuraw Iwan.

Kuwara benekis, merehuw, rawin, meceswey, Present (here) elders authorities compeers siblings

Lokah simu?

How are you all?

Peqasun balay niyux ta eseli Happy very right now we get together here Lalu mu ga Yuraw Iwan.

Name my is Yuraw Iwan.

Ladies and gentlemen, and how are you all? I am so happy here to know you all, and my name is Yuraw Iwan (Atayal student).
Faiaw, fakiaw, ato kita salikaka a mapolong, nga'ay ho? Ci Akiyo Pahalaan kako. Tada malipahak a matatikeda kita i tini.

Fai-aw, Faki-aw, ato kita sali-kaka a ma-polong, Ladies gentlemen and we siblings all nga'ay ho!

Fine(we are all fine.)

\section{Ci Takiko Pahalaan kako.}

Takio Pahalaan I (I am Takiko Pahalaan)

Tada ma-lipahak a matatikeda kita i tini.

Very pleased meet we here Ladies and gentlemen, and how are you all? I am pleased here to meet you all here, and my name is Takiko Pahalaan (Amis student).

\section{Methodology}

Action research (AR) is a form of structured reflection that requires the systematic collection and analysis of data, relating to the improvement of aspects of professional practice. For a teacher who activates and cultivates minority languages and cultures, AR is a powerful strategy for professional development: which raises questions about classroom practice, carefully documents procedures and gathers data through observation, interviews, and students' performance. Then the strategy encourages them to reflect on that data and practical experience to determine what to do next. This study uses Action Research as its primary investigative method, aided by observation and in depth interviews. 


\begin{tabular}{|c|c|c|c|}
\hline comparison & Reconfirm the spelling & Make a sentence & Dialogue \\
\hline $\begin{array}{c}\text { litemoh/ } \\
\text { litmoh } \\
\text { P.178 }\end{array}$ & $\begin{array}{c}\text { litemoh } \\
\text { [to meet、receive]p.178 }\end{array}$ & $\begin{array}{c}\text { Lipahak a mala-litemoh kita! } \\
\text { (Nice to meet you.) }\end{array}$ & $\begin{array}{c}\text { A:Sa-na'on-en. Aka ka litemoh-en ko citosiya. } \\
\text { B:Hai, ma-fana' to kako. }\end{array}$ \\
$\begin{array}{c}\text { A: Be careful. Never take a walk on the route of the car. } \\
\text { B:Yes. I got it. }\end{array}$ \\
\hline (practice another word) & & & \\
\hline
\end{tabular}

Literacy is a historical imperative for language revitalization and it must be a concern of the first order in this endeavour. In order to pronounce words from their spelling and to spell them from their sounds for those who have already mastered literacy in the dominant international language, English, I use AR in a multilingual classroom to prove that it would be much easier to learn a system of writing that uses letters found in the English alphabet, for the English experience can serve as a pronunciation guide allowing the learners by analogy to learn spelling in their own native languages (Yang, Yang. 2005). $\mathrm{AR}$, furthermore, is a process of analysis, getting facts, identifying the problem, planning and taking action on the problem, then repeating the cycle as new concepts and information result from the previous process. The present research will be conducted within the framework of AR which, like other forms of qualitative research, draws on a wide range of methods and sources of data. The primary methods of data collection are observation, interview, and documentary evidence (Edmondson \& Huang, 2004, 2005 ; Huang, T-C. 2002, 2014).

\section{Finding: An Orthography for Amis}

As Fishman (1980: 169) writes, 'Unless they are entirely withdrawn from the modern world, minority ethno-linguistic groups need to be literate in their mother tongue (as well as in some language of wider communication)'. However, the language becomes vastly easier to learn and literacy is improved when the writing system is consistent (Huang, T-C. 2002).

The preparation of materials for language awareness activities in multilingual classrooms in Taiwan is necessarily hampered by the fact that there is not a common orthography. Several different orthographic systems have been used at various times for each of the groups. Take the largest minority group, the Amis, for example. Table 4 below sets out the various ways in which the phonemes of the Amis has been represented (Edmondson, 1986; Fey, 1986, 1993; Huang, Tung-Chiou 1991, 1993, 1996; Edmondson \& Huang: 2004, 2005):

Table 4. Vowels and consonants have been devised in Amis language

Vowels

\begin{tabular}{|c|c|c|c|c|c|c|}
\hline $\begin{array}{c}\begin{array}{c}\text { Phonetic symbols \& } \\
\text { letters }\end{array} \\
\end{array}$ & $\begin{array}{c}\text { The similar sound in } \\
\text { English }\end{array}$ & Virginia Fey & $\begin{array}{c}\text { Ministry of } \\
\text { Education }\end{array}$ & Dr. Tsai \& Zeng & Hualien County & $\begin{array}{c}\text { Suggested writing } \\
\text { spelling } \\
\end{array}$ \\
\hline $\mathrm{Aa} / \mathrm{a} /$ & father & 'ap'ap & 'ap'ap & 'ap'ap & $\mathrm{ap}^{\wedge} \mathrm{ap}$ & ‘ap’ap \\
\hline $\mathrm{Ee} /$ a / & seven & mo’tep & mo'tep & mo’tep & mo^tep & moetep \\
\hline Ii /// & sitting & kilim & kilim & kilim & kilim & kilim \\
\hline $\mathrm{Oo} / \mathrm{o} /$ & open & opih & 'upih & opih & opih & opih \\
\hline $\mathrm{Uu} / \mathrm{u} /$ & June & fotig & foting & futing & futig & foting \\
\hline
\end{tabular}




\section{Consonants}

\begin{tabular}{|c|c|c|c|c|c|c|}
\hline $\begin{array}{c}\text { Phonetic symbols \& } \\
\text { letters }\end{array}$ & English & Virginia Fey & $\begin{array}{l}\text { Ministry of } \\
\text { Education }\end{array}$ & Dr. Tsai \& Zeng & Hualien County & $\begin{array}{l}\text { Suggested writing } \\
\text { spelling }\end{array}$ \\
\hline $\mathrm{Bb} / \mathrm{b} /$ & baby & & & & babahi & babahi \\
\hline $\mathrm{Cc} / \mathrm{ts} /$ & students & ccay & cecay & cecay & cecay & cecay \\
\hline $\mathrm{Dd} / \mathrm{t} /$ & dark & damdam & damdam & damdam & damdam & damdam \\
\hline $\mathrm{Ff} / \mathrm{f} /$ & fifth & falah & falah & falah & falah & falah \\
\hline $\mathrm{Gg} / \mathrm{g} /$ & good & & & & gris & geris \\
\hline $\mathrm{Hh} /[\mathrm{h}] /$ & him & hadhad & hadhad & hadhad & hadhad & hadhad \\
\hline $\mathrm{Kk} / \mathrm{k} /$ & clock & kakarayan & kakarayan & kakarayan & kakarayan & kakarayan \\
\hline $\mathrm{Ll} / \mathrm{l}] /$ & lily & lalag & lalang & lalang & lalang & lalang \\
\hline $\mathrm{Mm} / \mathrm{m} /$ & mother & mamana & mamana & mamana & mamana & mamana \\
\hline $\mathrm{Nn} / \mathrm{n} /$ & name & negneg & nengneng & nengneng & nengneng & nengneng \\
\hline $\mathrm{NG} / \mathrm{ng} / \mathrm{y} /$ & singing & gagan & ngangan & ngangan & ngangan & ngangan \\
\hline $\mathrm{Pp} / \mathrm{p} /$ & pen & papah & papah & papah & papah & papah \\
\hline $\mathrm{Qq} / \mathrm{q} /$ & & fo'is & foqis & fu'is & fu'is & fu'is \\
\hline $\mathrm{Rr} / \mathrm{r} /$ & ring & rara' & rara' & rara' & rara' & rara' \\
\hline Ss /s/ & sister & safa & safa' & safa' & $\mathrm{safa}^{\wedge}$ & safa \\
\hline $\mathrm{Tt} / \mathrm{t} /$ & stop & titi & piti & titi & titi & titi \\
\hline $\mathrm{Ww} / \mathrm{w} /$ & way & warwar & warwar & warwar & warwar & warwar \\
\hline $\mathrm{Xx} / \mathrm{x} /$ & loch & 'xiw & 'xiw & ^exiw & ^exiw & exiw \\
\hline $\mathrm{Yy} / \mathrm{j} /$ & yes & yatayat & yatayat & yatayat & yatayat & yatayat \\
\hline $\mathrm{Zz} / \mathrm{z} /$ & zoo & & & & zikut & zikut \\
\hline ‘ /?/ & network & 'a'am & 'a'am & 'a'am & $\mathrm{a}^{\wedge} \mathrm{am}$ & 'a'am \\
\hline$\wedge / \wedge /$ & & & & & $\mathrm{ap}^{\wedge} \mathrm{ap}$ & ‘ap'ap \\
\hline
\end{tabular}

Attempts to develop an orthography for Amis have thus been many and varied. Not all, however, observe the principles of economy, convenience and consistency. The use of the wedge $/ \wedge /$ to represent the sound of the glottal strop and its effects on the preceding or following vowel continues even in recent texts (Cu, Qing-Yi 2001), in spite of the fact that alternative representations which avoid this graph are possible, such as those the authors have pointed out, e.g. epah/ ^ pah; sienaw/ si^naw (Huang, T-C. 2002, 2014).

Over the past several years, there has been a focus on literacy in the mother tongues of Taiwan area, and the first author has been involved in a committee concerned with the development of orthographic conventions for the Amis language. He has set out below in Table 5, $6 \& 7$ the orthography which he used as the basis of the language awareness program. Only a small number of letters are used to represent sounds which do not occur in English and diacritics are avoided. Most letters are based on existing sound-letter relationships in English which means that students can also transfer their knowledge of English to the representation of aboriginal languages (Huang, T-C. 2002, 2014).

\begin{tabular}{|c|c|c|c|}
\hline 4 vowels & Front & Middle & Back \\
\hline High & Ii $/ \mathrm{i} /$ & & Oo $/ \mathrm{o} /$ \\
\hline Middle & & Ee $/ \mathrm{a} /$ & Aa $/ \mathrm{a} /$ \\
\hline Low & & \\
\hline
\end{tabular}


Table 5. 4 monophthongs and 19 consonants in the Amis language

\begin{tabular}{|c|c|c|c|c|c|c|c|}
\hline 19 consonant & bilabial & Labio-dental & alveolar & palatal & velar & pharyngeal & glottal \\
\hline stops & $\begin{array}{l}\mathrm{Pp} / \mathrm{p} / \\
\mathrm{Bb} / \mathrm{b} /\end{array}$ & & $\mathrm{Tt} / \mathrm{t} /$ & & $\begin{array}{r}\mathrm{Kk} / \mathrm{k} / \\
\mathrm{Gg} / \mathrm{g} /\end{array}$ & & $" / / 2$ \\
\hline nasals & $\mathrm{Mm} / \mathrm{m} /$ & & $\mathrm{Nn} / \mathrm{n} /$ & & NGng /y/ & & \\
\hline Trill/ Retroflex & & & $\mathrm{Rr} / \mathrm{r} /$ & & & & \\
\hline fricatives & & $\mathrm{Ff} / \mathrm{f} /$ & $\begin{array}{l}\mathrm{Ss} / \mathrm{s} / \\
\mathrm{Dd} / \mathrm{t} /\end{array}$ & & & $\mathrm{Xx} / \mathrm{x} /$ & $\mathrm{Hh} / \mathrm{h} /$ \\
\hline approximant & $\mathrm{Ww} / \mathrm{w} /$ & & & $\mathrm{Yy} / \mathrm{j} /$ & & & \\
\hline $\begin{array}{l}\text { Lateral } \\
\text { fricative }\end{array}$ & & & $\mathrm{L} 1 / 1 /$ & & & & \\
\hline affricate & & & & $\mathrm{Cc} / \mathrm{ts} /$ & & & \\
\hline
\end{tabular}

Table 6. The category of graphemes in the Amis language

\begin{tabular}{|c|c|c|}
\hline Categories & Graphemes & Number \\
\hline Vowels & $\mathrm{Aa} / \mathrm{a} /, \mathrm{Ee} / \mathrm{a} / \mathrm{Ii} / \mathrm{I} /, \mathrm{Oo} / \mathrm{o} /$ & 4 \\
\hline Glides/ consonants & $\mathrm{Ww} / \mathrm{w} /, \mathrm{Yy} / \mathrm{j} /$ & 2 \\
\hline Bilabial/ labiodental consonants & $\mathrm{Pp} / \mathrm{p} /, \mathrm{Bb} / \mathrm{b} /, \mathrm{Ff} / \mathrm{f} /, \mathrm{Mm} / \mathrm{m} /$ & 4 \\
\hline Velar consonants & $\mathrm{Kk} / \mathrm{k} /, \mathrm{Gg} / \mathrm{g} /, \mathrm{Xx} / \mathrm{x} /, \mathrm{NG} / \mathrm{ng} / \mathrm{y} /$ & 4 \\
\hline Palatal affricate & $\mathrm{Cc} / \mathrm{ts} /$ & 1 \\
\hline Voiceless lateral & $\mathrm{Dd} / \mathrm{t} /$ & 1 \\
\hline Glottals* & '/?/, $\mathrm{Hh} / \mathrm{\hbar} /$ & 2 \\
\hline Flapped or trilled sound & $\mathrm{Rr} / \mathrm{r} /$ & 1 \\
\hline
\end{tabular}

Table 7. One of the pronunciations in English corresponds to usage in the Amis language

\begin{tabular}{|c|c|c|c|}
\hline Grapheme & Phoneme & English & Amis/ Pangcah \\
\hline Aa & $/ \mathrm{a} /$ & are, farm, what, wash, father, hard, garden, & $\begin{array}{l}\text { ala }=\text { take, tala }=\text { wait, rara }=\text { slow, } \\
\text { rara' }=\text { red beans, latak }=\text { star fruit }\end{array}$ \\
\hline $\mathrm{Bb}$ & $/ \mathrm{b} /$ & $\begin{array}{l}\text { book, table, Bob, rabbit, bench, bring, } \\
\text { volleyball }\end{array}$ & babahi $=$ wife, baliyos $=$ typhoon \\
\hline $\mathrm{Cc}$ & /ts/ & students, elephants, streets, sports, habits, & cadiw $=$ sharpen, acek $=$ disgust, a'iloc $=$ neck, fangcal $=$ very good, cikay $=$ run \\
\hline $\mathrm{Dd}$ & $/ 1 /$ & $\begin{array}{c}\text { dark, idea, decision, dog, doctor, bedroom, } \\
\text { under, hard, weekend }\end{array}$ & dadipis $=$ cockroach, dipdip $=$ peek $/$ to secretly watch, sawad $=$ quit \\
\hline $\mathrm{Ee}$ & $/ \partial /$ & $\begin{array}{l}\text { sevene, quiet, often, enough, several } \\
\text { parent, elementary, }\end{array}$ & efeng $=$ throw away, kaen $=$ eat, likes $=$ mosquito, kemkem $=$ chew something \\
\hline $\mathrm{Ff}$ & $/ \mathrm{f} /$ & $\begin{array}{l}\text { flower, fifty, office, leaf, finish, fruit, } \\
\text { enough, telephone, }\end{array}$ & fali $=$ wind, falic $=$ exchange, kilif $=$ to be evasive $/$ not to tell truth, salof $=$ correct \\
\hline $\mathrm{Gg}$ & $/ \mathrm{g} /$ & girl, August, dog, & geliw $=$ string, galas $=$ glass, gris \\
\hline $\mathrm{Hh}$ & $/ \mathrm{h} /$ & he, her, here, hello, high, homework, hand, & $\begin{aligned} \text { hakowa }=\text { how } \operatorname{much} / \text { many, hakhak }=\text { rice, } \text { kaedah }=\text { peppery } / \text { hot, loyoh }=\text { to } \\
\text { collapes, mangah }=\text { lies, rihaday }=\text { peace }\end{aligned}$ \\
\hline Ii & $/ \mathrm{I} /$ & $\begin{array}{c}\text { this, sister, different, ticket, } \\
\text { picnic, winter, spring, }\end{array}$ & ina $=$ mother, 'icep= betel nut, 'idi= selfish, olili $=$ go ahead, wali= east \\
\hline $\mathrm{Kk}$ & $/ \mathrm{k} /$ & $\begin{array}{c}\text { key, jacket, park, skirt, walk, work, black, } \\
\text { thank }\end{array}$ & $\begin{array}{c}\text { kaeso' }=\text { delicious, karkar } / \text { korkor }=\text { dig, patonek }=\text { to set up } / \text { decide, sadak }=\text { come } \\
\text { out, tingki }=\text { electricity, }\end{array}$ \\
\hline $\mathrm{Ll}$ & $/ 1 /$ & lazy, dollar, football, & lakaw, lefek, licay, lolo= purple, luyuh= collapes, laloma'an, teloteloc, slal。 \\
\hline $\mathrm{Mn}$ & $/ \mathrm{m} /$ & milk, umbrella, room, similar, museum。 & $\begin{array}{l}\text { mamo, metmet, mi'mi', momok, muwa, malama, mato'asay, kilim, samsam, } \\
\text { radom。 }\end{array}$ \\
\hline $\mathrm{Nn}$ & $/ \mathrm{n} /$ & noise, stationary, invention, & nanam, nemnem, niyaro', nonor, nukay= go home, \\
\hline Oo & /o/ & $\begin{array}{l}\text { open, close, October, sofa, both, those, } \\
\text { clothes, cold }\end{array}$ & $\mathrm{oo}^{\prime}=$ leg, ocor $=$ send, olah $=$ love, tolo' $=$ fall down, niyaro' $=$ town, city \\
\hline $\mathrm{Pp}$ & $/ \mathrm{p} /$ & $\begin{array}{l}\text { popular, example, shop, power, pork, } \\
\text { company }\end{array}$ & pacpac $=$ beat hard, pedped $=$ crowd, pack soled, pihpih, podpod, puyapuy \\
\hline $\mathrm{Rr}$ & $/ \mathrm{r} /$ & real, terrible, sure, cheer, original & rara, rengreng, ridred=lead, riri', rosaros, rufu, rara' \\
\hline Ss & $/ \mathrm{s} /$ & slang, thirsty, dress, choice, delicious & sakasak, semsem $=$ suffer, silsil, solsol, sulep/cahiw \\
\hline $\mathrm{Tt}$ & $/ \mathrm{t} /$ & terrible, battery, meat, fight, control & tamita= Let's go, tengteng, tihtih, toto'/pa'pa, tupi/fanol \\
\hline $\mathrm{Uu}$ & $/ \mathrm{u} /$ & supermarket, June, junior, blue, true, & $\begin{array}{c}\text { tolon }=\text { pray, toron }=\text { sticky rice bread, toro' }=\text { point with the finger, } \text { kanoos }= \\
\text { finger nail }\end{array}$ \\
\hline $\mathrm{Ww}$ & $/ \mathrm{w} /$ & wok, what, & wakawak, widi= leeches, willet, widang, geliw \\
\hline $\mathrm{Xx}$ & $/ \mathrm{x} /$ & loch & capox, exiw, odax \\
\hline Yy & $/ \mathrm{j} /$ & yes, young & yatayat $=$ to exercise, kaying, yofing, siday, \\
\hline “' & $/ ? /$ & network & 'alo, 'ok'ok= drink, a'ayaw, fana' \\
\hline $\begin{array}{c}\mathrm{NG} / \\
\mathrm{ng}\end{array}$ & $/ \mathrm{y} /$ & language, stranger, drink, singing & ngangan, ngero'= tired, ngicngic, ngodo, ngusngus $=$ eat raw food \\
\hline
\end{tabular}


The following basic features and concepts of the Amis language can help learners read all the books published in Taiwan area (Edmondson \& Huang, 2001, 2004, 2005):

- An ergative VSO language with mostly prefixes, suffixes, a few infixes, and prepositions. There are lots of the ergative markers: $m a, p a$, sapi. Most words begin and end in consonants with a canonical word shape CVC...VC.

- Because it is a language that eschews words that begin or end with vowels, it hardens word onset and offset by covering initial or final vowels with a glottal stop, e.g. ina, ama, ocur, tusa, tulu, lima', 'api, 'ad'ad, fila', ngataa' (surprised). At the same time there are also examples of glottal stops that exist in the underlying form of a word.

- There are no consonant clusters, and therefore, when consonants come together, they must be assigned to different syllables, e.g. cikeroh, sepat...

- The root forms of many content words are nouns and verbs.

- Stress prominence always falls on the last syllable, except initial glottals followed by a have the accent on the first syllable, e.g. cima, ako, anengang, safa ako.

The phonogram and writing symbols are almost consistent: $\mathrm{Aa}, \mathrm{Bb}, \mathrm{Cc}, \mathrm{Dd}, \mathrm{Ee}, \mathrm{Ff}, \mathrm{Gg}, \mathrm{Hh}$, Ii, Kk, Ll, Mm, Nn, Oo, Pp, $\mathrm{Rr}$, Ss, Tt, Ww, Xx, Yy, NG/ng, and the glottal stop ', and it is easy to decode the sounds in the Amis language: 'alapit (chopsticks), babahi (wife), cikcik (cut up), dadaya (night), 'efeng (throw), fafoy (pig), galas (glass), hakhak (milled rice), itini (here), kakonah (ants), laklak (scatter), malenak (multiply), nanom (water), 'ocor (send), porong (to take long grass or twine and tie it in a knot to mark a trail in the mountains; a token to fight evil spirits), riyar (sea), sasaw (wash), tatata (let's go), wayway (behavior, impression), 'exiw (incense), yatayat (exercise), ngangan (name) and ' $a$ 'am (rice porridge).

Integrating aboriginal languages or students' cultural experiences into school subjects like English might enhance their learning and the most important of all is to give their languages a status more comparable to that of English or Mandarin, for Taiwan's diverse ethnicities and languages are a result of the island's history of immigration, and different ethnic groups have launched movements to preserve their languages and cultures in order to raise their status (Starkey, J. A. 2005)). There were, however, various aspects of this experience which could be harnessed to the benefit of the students, not least of which was the transfer of prior knowledge, particularly in relation to the use of an alphabetic writing system (Edmondson \& Huang, T-C. 2004, 2005; Huang, T-C. 2002, 2014). Some very interesting comments of overall assessment about the success of using an alphabetic writing system was offered by several of the Amis students after class in week nine:

I have learned the whole alphabet used in the Amis language: a, b, c, d, e, f, g, h, i, k, l, m, n, o, p, r, s, t, w, $\mathrm{x}, \mathrm{y}, \mathrm{ng}$, and the glottal stop "“".
In the Amis language $\mathrm{ABC}$ song, it is so interesting: $\mathrm{a}$, ba, ca, da, Nalowan; e, fe, ge, he, Nalowan; i, ki, li, mi, ni, Saicelen minanam (work hard in learning the ethnic language); o, po, rong (porong means a sign or a mark to fight against evils), sa, to, malenak (spread and multiply); o, wa, xa, ya, ng, '; caay to ka tongal ko roray a minanam to taneng no to'as (Learning the ethnic language is not arduous at all). It is interesting and easy to sing.

Each letter represents one speech sound. In the Amis language, there are severn phonemes in the word fa'edet : /f/ /a//'/ /e/ /d/ /e/ /t/, and there are three syllables in it. Blend the sounds /f/ /a/ / / /e//d/ /e/ /t/, and they become the word fa'edet (hot). Each syllable contains one vowel sound, like ki-a-ot, kiaot (run after). It is easier than English, isn't it?

The following examples are taken from my students' masterpieces which were created as a part of their fieldwork and ethnic language courses.

\section{Example 1}

Tona kara-tayal-ay ko Pangcah a finacadan saka, caay pi-harateng to sapi-holol-aw a mi-salama a tala-cowa-cowa. Caay ka-fana' ko Pangcah to saka-cietan-aw. Pa-edeng saan to ni-tayal-an nangra ko saka-'orip. Caay ka fana' to 'anof hananay. Tona adihay ko ma-kaen-ay no Pangcah a masa-maan-maan-ay a dateng no pala-pala-an saka, sa-raheker sa ko nika-'orip no Pangcah.

Because the Pangcah people were hard workers, they didn't think about taking off time to go places visiting. The Pangcah people had no knowledge about making money. They worked just so they could survive. They didn't have lust for anything out of sight. Since there were a lot of edible things to be gathered in the fields, they were content with their life.

\section{Example 2}

\section{Nanana! Idangaw}

Take it! My friends!

Roray to Pitoor to 'orip no Roma a Finacadan?

Weary follow life other people

Aka a pacefa a miala to caayay ko noniyaay a tatudung saan ko sowal no to'as,

Don't at will take not yourself belonging like that words ancestors

Kilami, naw miala ko Payrang to caayay ko nangraay a tatudung hakini?

However why take Han People not themselves belonging like that

Itiya ho, malalafang nomita cangra, paaro'en ita itini i kafiyaw nomita,

Then honorable guests our them give places to stay we here neighborhood us

Naw cangra to ko ci tatudungay to o lalengawan a tatudung nomita hakini?

Why they own original belongings our like that

Interpretation in English: Share and Reciprocity 
Take it as you wish, my friends! Is it tiring to catch up to the life style of other peoples? "Don't occupy what doesn't belong to you," said our ancestors. However, why do the Han peoples come into our lands and take out all that our ancestors left us? A long time ago, they were our honorable guests, and we treated them as family, giving them a piece of land to be our neighbors. How dare they are to become the lord of our original lands!

\section{Example 3 (folksong)}

\section{O 'ilol Ako ci Kakaan: Affection}

\section{Wang-wang sa ko waco, \\ The dog is continuously barking. o waco to dadaya?}

Is the dog barking normally?

Haya! O waco ko namimanay,

Aha! It couldn't be the barking of the dog,

Haya! O iyoy sa ni kaka.

Aha! It is the soft voice that my lover summons me with.

The barking of the dog

can be heard everywhere at midnight.

Can it be the sound of the barking dog?

Aha! It is the voice of my love.

Fiw-fiw sa ko fali,

o fali to safalat.

Haya! O fali ko namimanay/mami-maan,

haya! O licay sa ni kaka.

The wind is blowing softly,

It's a light gentle wind from the south.

Could it be just a tender breeze?

Aha! It's the lovely greeting from my love.

Siya-siya sa ko 'orad,

$o$ 'orad to lafii'.

Haya! O 'orad ko namimanay,

haya! O losa' sa ni kaka.

It rains dogs and cats,

It's always at midnight that it starts to rain.

Could it be the rain?

Aha! It's the tear of my love.

\section{Conclusions}

"Translingualism" is a process of empowerment, and this empowerment of us in our daily life might produce an environment that fosters maturity and responsibility. All student after participating in this course gradually realize that the main theme of "Translingualism" is the notion of the interdependence of languages and the transfer of skills, and they started understanding that the Chinese language uses a system of logographic characters that represent complete words or ideas (though this oversimplifies Han writing a bit, as its characters do have radical and phonetic, i.e. hints has meaning and sound); English is alphabetic in structure and uses graphemes to represent speech sounds, not concepts, words or syllables (Yang, Yang. 2005). It is believed that readers can extract meaning faster from logographs than from words in a phonetic writing system, whereas it is much easier to pronounce words in a phonetic system than from logographs; furthermore, as this paper explains, there has been a growing consensus over the past several years that the orthography of formerly unwritten languages should be based on the alphabetic principle, possibly as a result of the importance of English as a global language (Edmondson \& Huang, T-C. 2004, 2005 ; Huang, T-C. 2002, 2014).

In developing writing systems, there should ideally be one grapheme for each speech sound. This is also the principle that can be applied to the languages of Taiwan in the present project. The intention is to capitalize upon the fact that the students are already familiar with alphabetic writing because of prior study of English and the Romanized Chinese writing system. They would therefore be well-placed to transfer the regular sound-letter association which they have learned in English classes to the representation of the sounds of the various aboriginal languages of Taiwan (Kumar, Krishan 2003). For most students in Taiwan, consequently, it would be easier to learn a system of phonetics that uses letters found in the English alphabet that serve as a pronunciation guide while making analogy in learning aboriginal languages. 


\section{Appendix A: Transparencies used in the Language Awareness Activities}

\begin{tabular}{|c|c|c|c|c|c|c|}
\hline Letter & $\mathrm{Aa}$ & $\mathrm{Bb}$ & $\mathrm{Cc}$ & $\mathrm{Dd}$ & & \\
\hline $\begin{array}{c}\text { Phonemic representation of } \\
\text { letter name }\end{array}$ & $/ \mathbf{e} /$ & /bi/ & $/ \mathrm{si} /$ & $/ \mathrm{di} /$ & & \\
\hline Letter & $\mathrm{Ee}$ & $\mathrm{Ff}$ & $\mathrm{Gg}$ & $\mathrm{Hh}$ & & \\
\hline $\begin{array}{l}\text { Phonemic representation of } \\
\text { letter name }\end{array}$ & $/ \mathrm{i} /$ & $/ \varepsilon f /$ & $/ \mathrm{dg} \mathbf{i} /$ & /et $] /$ & & \\
\hline Letter & $\mathrm{Ii}$ & $\mathrm{Jj}$ & $\mathrm{Kk}$ & $\mathrm{Ll}$ & $\mathrm{Mm}$ & $\mathrm{Nn}$ \\
\hline $\begin{array}{c}\text { Phonemic representation of } \\
\text { letter name }\end{array}$ & $/ \mathrm{aI} /$ & /dgei/ & $/ \mathrm{ke} /$ & $/ \varepsilon 1 /$ & $/ \varepsilon \mathrm{m} /$ & $/ \varepsilon \mathrm{n} /$ \\
\hline Letter & Oo & $\mathrm{Pp}$ & $\mathrm{Qq}$ & $\mathrm{Rr}$ & Ss & $\mathrm{Tt}$ \\
\hline $\begin{array}{c}\text { Phonemic representation of } \\
\text { letter name }\end{array}$ & $/ \mathrm{o} /$ & $/ \mathrm{pi} /$ & $/ \mathrm{kju} /$ & /ar/ & $/ \varepsilon S /$ & $/ \mathrm{ti} /$ \\
\hline Letter & $\mathrm{Uu}$ & $\mathrm{Vv}$ & $\mathrm{Ww}$ & $\mathrm{Xx}$ & Yy & $\mathrm{Zz}$ \\
\hline $\begin{array}{l}\text { Phonemic representation of } \\
\text { letter name }\end{array}$ & /ju/ & /vi/ & /d $\Lambda$ blju / & /Eks / & $/ \mathrm{w}$ aI / & /zi/ \\
\hline
\end{tabular}

The vowels we can learn from the table above are:

//;//;//;//;//;//;//;//;//;//;//;//;

//; / /; / / / /; / /; / / / /; / /; / /; / /; /, / /;

The consonants we can find from the table above are:

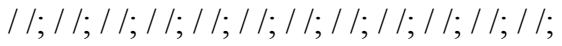

I/;//;//;//;//;//;//;//;//;//;//;//;

\section{Appendix B: The alliteration and rhyme of the letter-sound correspondences}

\begin{tabular}{|c|c|c|c|c|c|}
\hline & $\begin{array}{l}\mathrm{Aa} \\
\mathrm{a} / \mathrm{a}\end{array}$ & $\begin{array}{l}\mathrm{Ee} \\
/ \partial /\end{array}$ & $\begin{array}{l}\mathrm{Ii} \\
/ \mathrm{I} /\end{array}$ & $\begin{array}{l}\mathrm{Ooo} \\
\mathrm{o} / \mathrm{O}\end{array}$ & $\begin{array}{l}\mathrm{Uu} \\
/ \mathrm{u} /\end{array}$ \\
\hline $\mathrm{Aa} / \mathrm{a} /$ & $\mathrm{AA} / \mathrm{aa}$ & $\mathrm{AE} / \mathrm{ae}$ & $\mathrm{AI} / \mathrm{ai}$ & $\mathrm{AO} / \mathrm{ao}$ & $\mathrm{AU} / \mathrm{au}$ \\
\hline $\mathrm{Bb} / \mathrm{b} /$ & $\mathrm{BA} / \mathrm{ba}$ & BE/be & $\mathrm{BI} / \mathrm{bi}$ & $\mathrm{BO} / \mathrm{bo}$ & $\mathrm{BU} / \mathrm{bu}$ \\
\hline $\mathrm{Cc} / \mathrm{ts} /$ & $\mathrm{CA} / \mathrm{ca}$ & $\mathrm{CE} / \mathrm{ce}$ & $\mathrm{CI} / \mathrm{ci}$ & $\mathrm{CO} / \mathrm{co}$ & $\mathrm{CU} / \mathrm{cu}$ \\
\hline $\mathrm{Dd} / \mathrm{t} /$ & $\mathrm{DA} / \mathrm{da}$ & $\mathrm{DE} / \mathrm{de}$ & $\mathrm{DI} / \mathrm{di}$ & $\mathrm{DO} / \mathrm{do}$ & DU/du \\
\hline $\mathrm{Ee} / \partial /$ & EA/ea & EE/ee & EI/ei & $\mathrm{EO} / \mathrm{eo}$ & EU/eu \\
\hline $\mathrm{Ff} / \mathrm{f} /$ & $\mathrm{FA} / \mathrm{fa}$ & $\mathrm{FE} / \mathrm{fe}$ & $\mathrm{FI} / \mathrm{fi}$ & $\mathrm{FO} /$ fo & FU/fu \\
\hline $\mathrm{Gg} / \mathrm{g} /$ & GA/ga & GE/ge & $\mathrm{GI} / \mathrm{gi}$ & $\mathrm{GO} / \mathrm{go}$ & $\mathrm{GU} / \mathrm{gu}$ \\
\hline $\mathrm{Hh} /[\mathrm{h}] /$ & $\mathrm{HA} / \mathrm{ha}$ & HE/he & $\mathrm{HI} / \mathrm{hi}$ & HO/ho & $\mathrm{HU} / \mathrm{hu}$ \\
\hline Ii /I/ & IA/ia & IE/ie & II/ii & $\mathrm{IO} /$ io & IU/iu \\
\hline $\mathrm{Jj} / \mathrm{d} / /$ & $\mathrm{JA} / \mathrm{ja}$ & $\mathrm{JE} / \mathrm{je}$ & $\mathrm{JI} / \mathrm{ji}$ & $\mathrm{JO} / \mathrm{jo}$ & $\mathrm{JU} / \mathrm{ju}$ \\
\hline $\mathrm{Kk} / \mathrm{k} /$ & $\mathrm{KA} / \mathrm{ka}$ & KE/ke & $\mathrm{KI} / \mathrm{ki}$ & $\mathrm{KO} / \mathrm{ko}$ & $\mathrm{KU} / \mathrm{ku}$ \\
\hline $\mathrm{Ll} / 1] /$ & LA/la & LE/le & $\mathrm{LI} / \mathrm{li}$ & $\mathrm{LO} / \mathrm{lo}$ & LU/lu \\
\hline $\mathrm{Mm} / \mathrm{m} /$ & $\mathrm{MA} / \mathrm{ma}$ & $\mathrm{ME} / \mathrm{me}$ & $\mathrm{MI} / \mathrm{mi}$ & $\mathrm{MO} / \mathrm{mo}$ & $\mathrm{MU} / \mathrm{mu}$ \\
\hline $\mathrm{Nn} / \mathrm{n} /$ & $\mathrm{NA} / \mathrm{na}$ & $\mathrm{NE} / \mathrm{ne}$ & $\mathrm{NI} / \mathrm{ni}$ & $\mathrm{NO} / \mathrm{no}$ & $\mathrm{NU} / \mathrm{nu}$ \\
\hline $\mathrm{NG} / \mathrm{ng} / \mathrm{y} /$ & NGA/nga & NGE/nge & NGI/ngi & $\mathrm{NGO/ngo}$ & NGU/ngu \\
\hline $\mathrm{Oo} / \mathrm{o} /$ & $\mathrm{OA} / \mathrm{oa}$ & $\mathrm{OE} / \mathrm{oe}$ & $\mathrm{OI} / \mathrm{oi}$ & $\mathrm{OO} / \mathrm{oo}$ & OU/ou \\
\hline $\mathrm{Pp} / \mathrm{p} /$ & $\mathrm{PA} / \mathrm{pa}$ & $\mathrm{PE} / \mathrm{pe}$ & $\mathrm{PI} / \mathrm{pi}$ & $\mathrm{PO} / \mathrm{po}$ & $\mathrm{PU} / \mathrm{pu}$ \\
\hline $\mathrm{Qq} / \mathrm{q} /$ & $\mathrm{QA} / \mathrm{qa}$ & $\begin{array}{c}\mathrm{QE} / \mathrm{qe} \\
\text { qemusun }\end{array}$ & $\begin{array}{l}\text { QI/qi } \\
\text { Fo'qis }\end{array}$ & $\begin{array}{l}\text { QO/qo } \\
\text { qoyo }\end{array}$ & $\mathrm{QU} / \mathrm{qu}$ \\
\hline $\mathrm{Rr} / \mathrm{r} /$ & $\mathrm{RA} / \mathrm{ra}$ & $\mathrm{RE} / \mathrm{re}$ & $\mathrm{RI} / \mathrm{ri}$ & RO/ro & $\mathrm{RU} / \mathrm{ru}$ \\
\hline $\mathrm{Ss} / \mathrm{s} /$ & $\mathrm{SA} / \mathrm{sa}$ & $\mathrm{SE} / \mathrm{se}$ & $\mathrm{SI} / \mathrm{si}$ & SO/so & $\mathrm{SU} / \mathrm{su}$ \\
\hline $\mathrm{Tt} / \mathrm{t} /$ & $\mathrm{TA} / \mathrm{ta}$ & TE/te & $\mathrm{TI} / \mathrm{ti}$ & TO/to & $\mathrm{TU} / \mathrm{tu}$ \\
\hline $\mathrm{Uu} / \mathrm{u} /$ & UA/ua & UE/ue & $\mathrm{UI} / \mathrm{ui}$ & UO/uo & UU/uu \\
\hline $\mathrm{Vv} / \mathrm{v} /$ & $\mathrm{VA} / \mathrm{va}$ & VE/ve & $\mathrm{VI} / \mathrm{vi}$ & VO/vo & $\mathrm{VU} / \mathrm{vu}$ \\
\hline $\mathrm{Ww} / \mathrm{w} /$ & WA/wa & WE/we & WI/wi & WO/wo & WU/wu \\
\hline $\mathrm{Xx} / \mathrm{x} /$ & $\mathrm{XA} / \mathrm{xa}$ & $\mathrm{XE} / \mathrm{xe}$ & $\begin{array}{c}\mathrm{XI} / \mathrm{xi} \\
\mathrm{xiw} \\
\end{array}$ & $\begin{array}{c}\mathrm{XO} / \mathrm{xo} / \mathrm{ox} \\
\text { capox }\end{array}$ & $\mathrm{XU} / \mathrm{xu}$ \\
\hline $\mathrm{Yy} / \mathrm{j} /$ & YA/ya & YE/ye & $\mathrm{YI} / \mathrm{yi}$ & $\mathrm{YO} /$ yo & YU/yu \\
\hline $\mathrm{Zz} / \mathrm{z} /$ & $\mathrm{ZA} / \mathrm{za}$ & ZE/ze & $\mathrm{ZI} / \mathrm{zi}$ & $\mathrm{ZO} / \mathrm{zo}$ & $\mathrm{ZU} / \mathrm{zu}$ \\
\hline $\begin{array}{l} \\
/ ? /\end{array}$ & $\begin{array}{c}\mathrm{A} /{ }^{\prime} \mathrm{a} \\
\text { na'ay= refuse }\end{array}$ & $\begin{array}{l}\text { 'E/'e } \\
\text { la'ed }\end{array}$ & $\begin{array}{c}\text { 'I/ 'i } \\
\text { ma'ifor/di'i }\end{array}$ & $\begin{array}{l}\text { 'O/'o } \\
\text { na'on }\end{array}$ & $\begin{array}{l}\text { 'U/'u } \\
\text { ma'usi }\end{array}$ \\
\hline
\end{tabular}




\section{REFERENCES}

[1] Barreiro, Marco. (1999). A reflection on the English orthography.

http://www.terra.es/personal2/marcovelez/filoloxi/essays/ort hogra.htm

[2] Bees, Seb. (1995). How Can I Respond Pupils' Educational Needs in my Teaching of History? Greendown School, Swindon, Wiltshire, U.K. http://www.auckland.ac.nz/msis/is world/action.htm (accessed October, 1997).

[3] Berry, J. (1972). The making of alphabets. In Joshua A. Fishman (ed.) Readings in the sociology of language. The Hague: Mouton, 737-753.

[4] Burnaby, Baraba. (1997). Writing systems and orthographies. In Viv Edwards and David Corson (Eds.). Encyclopedia of Language and Education. Volume 2, Literacy. Netherlands: Kluwer Academic Publishers, 77-86.

[5] Campbell, George L. (1997). Handbook of scripts and alphabets. London: Routledge.

[6] Chen, Li-Hung. (1993). Chinese language. http://members.n bci.com/_XMCM/charlih/chinese/chineselanguage.htm

[7] Cheng, Yuen-Ching. (1994). Taiwan's Aboriginal Culture (I). Taipei: Sinorama Magazine.

[8] Cheng, Yuen-Ching. (1997). Taiwan's Aboriginal Culture (II). Taipei: Sinorama Magazine.

[9] Coulmas, F. (1989). The writing systems of the world. Basil Blackwell, Oxford.

[10] Coulmas, F. (1996). The Blackwell encyclopedia of writing systems. Basil Blackwell, Oxford.

[11] Craig, Robert \& Alexander, Antony. (2001). A fully democratic approach towards an international auxiliary language initially based on reformed English. http://www.alexander.iofm.iofm.net/lang32.htm

[12] DeLancey, Scott. (1998). Orthographies for Australian Aboriginal languages. http://linguistlist.org/ ask-ling/archie v-1998.1/msg01534.html (accessed 03 August, 2000).

[13] Deniels, Peter T. \& William Bright, eds. (1996). The world's writing systems. New York: Oxford University Press.

[14] Diaz-Rico, L. (2004). Teaching English Learners: Strategies and Methods. San Francisco: Pearson Education.

[15] Edmondson, Jerold A. \& Huang, T-C (2004) Phonological strengthening in Hsiukuluan Amis.In Somesonge Burusphat, Papers from the Eleventh Annual Meeting of the Southeast Asian Linguistics Society 2001. America: Arizona State University, pp. 263-273.ISBN 1-881044-34-3.

[16] Edmondson, J.A, Esling, J., Harris, J.G..\& Huang, T-C (2005) Alaryngoscopic study of the glottal, epiglottal, and pharyngeal stops and continuants in Amis: an Austronesian language of Taiwan. Language and Linguistics. Volume 6 Number 3, 2005.Institute of Linguistics, Academia Sinica, pp. 381-396. ISSN1606-822X, July 2005.

[17] Ferrell, Raleigh. (1969). Taiwan Aboriginal Group: Problems in Cultural And Linguistic Classification. Taiwan: Academic Sinica.

[18] Fey, Virginia. (1986). Amis Dictionary. Taiwan: The Bible Society.

[19] Fey, Virginia. (1993). Amis culture. Taiwan: The Bible Society.

[20] Fishman, Joshua. (1980). Minority language maintenance and the ethnic mother tongue school. Modern Language Journal, 64(2), 167- 172 .

[21] Gelb, I.J. (1963). A study of writing (second edition). University of Chicago Press, Chicago.

[22] Her, Der-hwa. (1994). The scientific and social principles of writing systems for the Austro-Polynesian languages. In R.K. $\mathrm{Li}$ and $\mathrm{Y}$. Lin (eds) Collection of Books on the Austro-Polynesian Languages in Taiwan (pp. 140-157). Council on Educational Research, Ministry of Education.

[23] Hodges, Richard E. (1996). Spelling, ERIC Digest. http://www.ed.gov/databases/ERIC_Digests/ed250695.html

[24] Hoosain, Rumjahn. (1995). Getting at the sound and meaning of logographic and alphabetic scripts. In I. Taylor \& D. R. Olson (eds.) Scripts and Literacy. Dordrecht / Boston/ London: Kluwer Academic Publishers, 131-144.

[25] Huang, Lillian M. (1995). A typological overview of nominal case marking systems of Formosan languages. Book presented at The Second International symposium on the Languages in Taiwan (June 3-4 1995). Taipei: National Taiwan University.

[26] Huang, Tung-Chiou. (1991). Sikifag, Provincial Boys' Senior High School. Taipei: The Crane Publishing Co., Ltd.

[27] Huang, T.C. (1994). Minanam To Sowal No Toías Pakayni I Radiw. Yian-Shan Publishing Cooperation, Taiwan.

[28] Huang, T.C. (2002). Indigenous Languages and TEFL in a Senior High School in Taiwan. The University of Reading: Unpublished Ph.D thesis.

[29] Huang, T-C. 2014. "Self, Culture and Justice-The Role of Language: Translingualism.” International Journal of Recent Advances in Organizational Behaviour and Decision Sciences (IJRAOB) An Online International Research Journal (ISSN: 2311-3197) 2014 Vol: 1 Issue 3. http://www.globalbizresearch.org/ob/issues.php?id=43

[30] Kumar, Krishan. (2003). The Making of English National Identity. Cambridge: Cambridge Cultural Social Studies.

[31] Li, Paul J. K. (1995). The distribution of the Austronesian languages in Taiwan and the migration of their speakers. In F.F Tsao and M. Tsai (eds) Books from the First International Symposium on Languages in Taiwan. Taipei: Crane (in Chinese), pp. 1-16.

[32] Owocki, G. M. \& Goodman, Y. M. (1997). The teaching of writing. In Viv Edwards and David Corson (Eds.). Encyclopedia of Language and Education. Volume 2, Literacy. Netherlands: Kluwer Academic Publishers, 77-86.

[33] Rogers, Henry. (1995). Optimal orthography. In I. Taylor \& D. R. Olson (eds.) Scripts and Literacy. Dordrecht/Boston/London: Kluwer Academic Publishers, 31-44. 
[34] Starkey, J. A. (2005). Multicultural Communication Strategies: How to Be More Successful with Customers, Colleagues and Community. Chicago, Illinois: The Starkey Group.

[35] Tatham, Mark. (1998). Consonant and vowel charts. http://www.essex.ac.uk/speech/teaching/lg111/charts/charts. html

[36] Taylor, I. \& Olson, D.R. (1995). An introduction to reading the world's scripts. In I. Taylor \& D. R. Olson (eds.) Scripts and Literacy. Dordrecht / Boston/ London: Kluwer Academic Publishers, 1-15.

[37] Tsao, Feng-fu. (1996a). Language Education in Taiwan: A review in socio-linguistic perspective. In P. Storey et al. (eds) Issues in Language in Education (pp. 153-166). Hong-Kong: The Hong-Kong Institute of Education.

[38] Tsao, Feng-fu. (1997a). Ethnic Language Policy: A Comparison of the Two Sides of the Taiwan Straits. Taipei:
Crane (in Chinese).

[39] Tsao, Feng-fu. (1997b). Preserving Taiwan's Aboriginal Language and Cultures: A discussion in sociolinguistic perspective. In N. Inoue (ed.) Globalization and Aboriginal Culture (pp. 97-112). Tokyo: Institute for Japanese Culture and Classics, Kokugakuin University.

[40] Tsao, Feng-fu. (1999). The Language Planning Situation in Taiwan. Journal of Multilingual and Multicultural Development Vol. 20, Nos, 4 \& 5.

[41] Tse, K.P. (1986). Standardisation in Chinese in Taiwan. International Journal of Sociology of Language 59, 25-32.

[42] Tung, Masegseg C. (1996). The Exquisite Heritage: The culture and arts of Taiwan aborigines. Taipei: Rainbow Sign Publishing Company.

[43] Yang, Yang. (2005). Making sense of English. Shanghai Star. [on line] available from http://app1.chinadaily.com.cn/star/2 005/0324/fo 7-1.html (accessed May 3, 2005). 